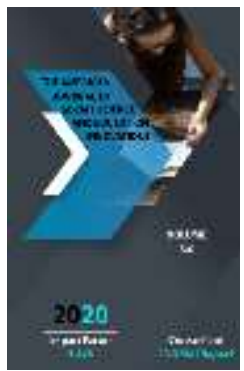

\title{
Sociolinguistic Competence As A Purpose Of Teaching A Nongene (Russian) Language In A Secondary School
}

\author{
Alimsaidova Sayyora Amideevna \\ Candidate Of Pedagogical Sciences, Associate Professor, Department Of Russian Language \\ And Literature, Kokand State Pedagogical Institute Named After Mukimi, Uzbekistan
}

Journal Website: http://usajournalshub.c om/index,php/tajssei

\section{ABSTRACT}

The article presents the results of research on the effectiveness of the use of sociolinguistic competence in teaching Russian in a school with the Uzbek language of instruction; the importance of the formation of sociolinguistic competence is shown, which will allow students to successfully implement their communicative intentions in natural communication situations, both with speakers of a non-native (Russian) language, and with students of the same language as a non-native language.

\section{KEYWORDS}

Sociolinguistics, competence, national-cultural component of the meaning of the word, communication, knowledge, abilities, skills.

\section{INTRODUCTION}

In connection with the improvement of the modern education system in the Republic of Uzbekistan by the principles of humanization and democratization of society, the goal of each school subject corresponding to the school curriculum is to contribute to the achievement of the social order of society for the preparation and intensive formation of a free, developed, educated and successful personality capable of living and creating. in a constantly changing world.

In modern science, this is interpreted as an ideal, consciously planned image of the result of the educational process in its relation to the conditions that generate it, which is expressed in the changes occurring in knowledge, skills, 
personal qualities, in the enrichment of value orientations of the worldview, sociocultural, intellectual nature $[6,82]$.

The goal of teaching a non-native (Russian) language in a general education school is the formation of sociolinguistic competence as an ability, in accordance with communication situations and taking into account the communicative goal, social status and roles of communicants, relations between them and the place of communication, to organize their speech behavior in accordance with the sociolinguistic norm and attitudes of a specific national-linguistic-cultural community (Uzbek) and choose the necessary list of communication within the framework of the official, neutral and unofficial side of communication.

\section{MATERIALS AND METHODS}

The process of formation and development of sociolinguistic competence is possible on the basis of the sum of certain acquired knowledge, formed skills, developed skills and attitude to activity.

When studying a non-native (Russian) language, socialization, the assimilation of linguistic norms and rules of the culture of society occurs in an unnatural way. A person involuntarily transfers speech, language rules, habits, traditions of society, family, culture where he grew up and was brought up, into communication in a foreign language, into the environment of foreign language communication and culture, which is called linguistic transfers, which are both positive (transposition), and and negative (interference).

If the former can actually help communicators in the implementation of communication, the latter lead to difficulties in communicating with native speakers, and even to communication failures. This means, in our opinion, the gradual mastering by students of sociolinguistic knowledge, skills and abilities and attitudes to activities in the formation of sociolinguistic competence will allow students to successfully realize their communicative intentions in natural communication situations, both with speakers of a non-native (Russian) language, and with students of the same language as a foreign language.

Having considered the works of domestic and foreign sociolinguists (Andriyanova V.I., Akhmedova L.T., Belikov V.I., Vakhtin N.B., Ziyaeva S.A., Krysin L.P., Mechkovskaya N.B., Schweitzer A.D. and others), and also, having studied the structure of sociolinguistic competence in the works of scientists, we came to the conclusion that sociolinguistic knowledge, skills and abilities are broad in composition.

When selecting them for a general education school, we aimed at the component composition of sociolinguistic competence:

> Sociolinguistic knowledge;

$>$ Sociolinguistic skills;

$>$ Sociolinguistic skills.

\section{RESULTS AND DISCUSSION}

Sociolinguistic knowledge is a structured system. In the fair opinion of V.V. For the Reds, knowledge can be nationally neutral and nationally marked. Nationally marked are surrounded by a culturally significant halo and occupy a special position in culture [4]. Knowledge "regulates the relationship between communicants long before the start of communication" [2, 85-86].

Theoretical knowledge about the essence and meaning of sociolinguistic competence forms a 
general idea of the structure of communicative competence and its components, the essence and structure of sociolinguistic competence, the role and importance of mastering it for successful intercultural communication. Students are introduced to concepts that are new to them in an introductory lecture, as well as in conversations on intercultural topics throughout the course.

Theoretical knowledge about the norms and models of behavior in communicative situations of communication implies the awareness by students of the sociolinguistic norms of speech behavior of Russian-speaking (Russians), which differ from Uzbek in significant originality. For example, the principle of tact when communicating with elders is an important linguistic and social characteristic of the speech behavior of Uzbeks. Uzbek hospitality prescribes mandatory adherence to the norms of behavior, in which the guest is equated with the older members of the family and Hospitality is one of the characteristic features of the people of Uzbekistan. The ability to receive a guest is valued by Uzbeks above the wealth of the table itself or the wealth of the family. Not accepting a guest means dishonoring the family, clan, makhalla, village. Even the enemy could not be denied hospitality. [11].

Knowledge of patterns of behavior in communicative situations of communication also presupposes knowledge of the characteristic dominant features of Uzbek communicative behavior: affability (demonstration of disposition and attention to others) and communicative gentleness (inadmissibility of addressing "you", even in relation to a young child). Knowledge of the models of behavior in communicative situations of communication typical for a given national-linguistic-cultural community, as well as knowledge of the basic sociolinguistic conditions of a communicative situation, should be offered to students at the very beginning of the educational course.

Theoretical knowledge of sociolinguistic conditions (context) of a communicative situation is one of the main ones in this article. Knowledge of sociolinguistic conditions is more social than linguistic perception of where, between whom and under what conditions communication takes place, for which knowledge is necessary about the purpose and place of communication, social statuses and roles of communicants, as well as the relationship between them. In our opinion, these sociolinguistic conditions of the communicative situation affect the correct choice of communication, and, as a consequence, the success of communication in general.

Linguistic knowledge is represented by knowledge of certain linguistic forms (speech cliches, speech etiquette formulas), which can be used by students in the necessary areas of communication when implementing various communicative intentions (requests, orders, clarifications, etc.) depending on the communicative situation of communication, with which students are directly acquainted with during the learning process in practical classes in a non-native (Russian) language.

In the fair opinion of S.F. Shatilov, the presence of automated components in any activity, including speech, is a necessary condition for its successful implementation $[10,24]$. The importance of skills as automated components of activity is enormous: they free the student's consciousness from regulating individual actions to solve creative problems.

The sociolinguistic skill of recognizing the formulas of verbal communication that carry out a certain communicative intention, in 
accordance with the communicative situation of communication, is inherently linguistic. "At the same time, language skills are a kind of" conscious part 'of speech skills" [10, 27]. By this concept, we mean - the skill of operating with linguistic material in conditions of productive intercultural communication, when the participants learn the speech characteristics of the behavior of representatives of a foreign language (Russian) culture and correlate them with the sociolinguistic conditions of the communicative situation while realizing the national and cultural conditionality of language and speech behavior.

The sociolinguistic skill of recognizing the communication list is an intellectual skill. Possessing it, students in the course of mental activity learn, determine and choose the necessary means of communication for the implementation of successful communication, when, to one degree or another, mutual understanding is achieved between speech partners.

The sociolinguistic skill of using pragmatic clichés is the language skill of using the desired pragmatic cliché in each particular situation, depending on the sociolinguistic context. Having determined the necessary tonality for communication, the trainees select and use the necessary formulas of speech etiquette to realize their speech intention (goal) of communication.

Sociolinguistic skills can be defined as the correspondence of mutual understanding between the carriers of different nationallinguistic-cultural communities in the conditions of intercultural communication, which is determined by the degree of coincidence of the images of their consciousness. This "sets itself the task of comprehending the socio-cultural portrait of the countries of the target language, sociocultural politeness, speech tact, which is possible if the learning process is carried out in the context of a dialogue of cultures" $[1,71]$. The dialogue of cultures is interpreted by modern psycholinguistics not in the spirit of traditional linguistic and cultural studies and the volume of sociocultural knowledge, but by "the presence of the qualities of consciousness that were formed as a result of the appropriation of the sociocultural potential of the country of the target language" [9, 112]. These qualities are understood as images of consciousness associated with words. A real dialogue of cultures can only take place in the consciousness of the bearer of a particular culture, who managed to comprehend the images of consciousness of another (alien) culture, the dialogue of cultures is not so much communication of different consciousnesses as communication of images of different cultures within the framework of one awareness [9].

Of the skills included in the structure of intercultural competence, the most important is the ability to understand "someone else's" in the broadest sense. Research in the field of national and cultural features of text construction ethnopsycholinguistics, linguo-cultural studies) will open the door to the world of "ours" and give "keys" to the world of "aliens" [4, 317]. As noted by N.V. Filippova, "the development of the ability to understand the" alien "implies the awareness of the cultural conditioning of communicative actions, the development of sensitivity to the " alien ", the ability to compare cultures and perceive culture through the eyes of its carriers. With an intercultural approach, teaching a non-native (Russian) language is structured in such a way that each foreign language and foreign cultural phenomenon is considered in the whole context of a given culture. This provides a gradual advance from understanding a 
separate statement to understanding a communication partner, and through this to understanding a different culture as a whole "[7, 81]. From this perspective, let's consider each of the sociolinguistic skills in more detail.

The ability to recognize and select formal, neutral and informal communication styles in accordance with a specific situation lies in the ability of students to socially differentiate the use of linguistic units and their variants in formal, neutral and informal communication. Then, the purpose of communication, the social statuses and roles of speakers, the relationship between them, the place of communication are determined, and, as a result, this skill presupposes a conscious choice by students of the communication style in a specific situation and in dynamics. The ability to recognize and choose a communication style, in addition, is directly related to the mechanism of changing the stylistic pattern of speech. In the context of teaching sociolinguistic competence, this is one of the basic skills as soon as the correct choice of the communication situation before the start of communication will allow it to start - continue finish in the future in accordance with the sociolinguistic norms of this national-linguisticcultural community.

The ability of verbal behavior, fulfilling the necessary communicative intention, corresponding to the situational sociolinguistic norm and the socio-cultural context, is speech actions with certain linguistic units in order to solve educational and cognitive tasks in the learning process and in order to successfully establish, maintain, and end a communicative act in real life conditions. intercultural communication. This skill is realized through the skills: to initiate / establish / involve in interpersonal contacts, including real communication, taking into account the cultural norms of the country of the target language; carry out (develop / maintain) interpersonal contacts, taking into account the cultural norms of the country of the target language, establishing the degree of coincidence / non-coincidence of the trainees' points of view; to adequately verbally respond to the responses and behavior of the interlocutor / $\mathrm{s}$, formulating their thoughts logically, consistently, and showing interest, attention and active participation in the conversation.

The ability to carry out (develop / maintain) interpersonal contacts, taking into account the cultural norms of the country of the target language, establishing the degree of coincidence / non-coincidence of the points of view of the participants in communication implies the ability of students to take responsibility for the course of verbal communication with representatives of the country of the target language. Within the framework of this skill, trainees must also develop the ability to tolerate and correctly, depending on the sociolinguistic conditions of the communicative situation, act as a speech partner, having mastered various status-role strategies of speech behavior, and also be responsible for the success of the act of communication.

The ability to adequately respond verbally to the responses and behavior of the interlocutor I s, formulating their thoughts logically, consistently, and showing interest, attention and active participation in the conversation is a speech skill. As part of the formation of sociolinguistic competence in secondary school students, it develops on the basis of previous skills. It is possible to verbally respond to cues and behavior in real communication conditions only if the communication process develops, and if the communication participants really understand each other. 
Ability to create a communicative portrait of the participant (s) of intercultural communication. The image of a new interlocutor is formed in the first minutes of interaction, and is based on the first impression, which we correlate the interlocutor's behavior (including speech) with our previous experience and assign him to some previously formed group.

In official communication, a person acts as follows: he correlates the behavior of a person as a professional, and then, sometimes during subsequent contacts, highlights the individual and personal characteristics of the speech partner [8, 2003]. And as a result, in the professional sphere, at the very beginning of contact, there is often an interaction of roles, masks, and not personalities. In general, this skill consists in anticipating the strategies and tactics of the communicative behavior of the interlocutor, recognizing his desires and intentions, psychological characteristics, motives, position and relationships, social status and emotional roles of the participants in communication.

The ability to analyze your speech behavior and carry out speech correction in order to avoid possible communication mistakes in subsequent communication in a non-native (Russian) language is one of the main ones. This skill should be classified as educational. In the process of teaching a non-native (Russian) language as part of the school curriculum, students prepare for real intercultural communication, in particular for oral communication. In the context of natural and not educational communication in a non-native (Russian) language, there is no teacher who will help, correct, comment on mistakes, talk about acceptable or unacceptable behavior, etc. And as a result, absolutely all responsibility for all communication lies directly with the student, who, realizing the presence of erroneous speech actions in his speech, which could presumably offend his interlocutor, lead to misunderstandings or to communication failure, should be able to independently analyze his speech behavior, find out the reason communicative failure, independently find information (from books, private conversations, observations, introspection ...) on how to properly organize your speech behavior in accordance with sociolinguistic norms and attitudes of a particular nationallinguistic-cultural community. This skill also presupposes the mastery of trainees' ability to predict and analyze difficulties in the process of communication; evaluate and interpret the incoming sociolinguistic information using guesswork, observation and personal speech experience; an apology for not knowing the norms of speech behavior.

One of the most important components of the content of teaching a non-native (Russian) language is the attitude to activity and its motives. According to social psychologists, the most characteristic social motivation is the socalled "motivation for success", the desire to achieve success in a socially innovative society $[3,44]$.

\section{CONCLUSION}

The formation of sociolinguistic competence is impossible without fostering a tolerant attitude of students to the differences between the culture of the country of the target language (Russian) and the native (Uzbek) culture, according to the principle of the dialogue of cultures; orientation of trainees to the implementation of successful communication, to "sociolinguistic impartiality", that is, to "the absence of ethnopsychological prerequisites for sociolinguistic interference" [6, 107]; without introducing students to the use of the acquired sociolinguistic knowledge, skills and abilities in 
the course of real or educational communication in a foreign language; orientation towards sociolinguistic susceptibility to the detection of trends in the interaction of the general and the different between the native and the target languages and cultures. The development of empathy as the ability to imagine oneself in the place of another, to understand his feelings, desires, ideas and actions is also an important component of sociolinguistic competence. All of the above constitutes the fourth component of the training content - the attitude towards communication partners, the culture they represent, intercultural communication and the process of mastering a non-native (Russian) language in general.

We believe that completing assignments according to the proposed teaching methodology is impossible without a positive attitude towards other students and the teacher as speech partners. Therefore, here conversations on the problems of intercultural communication will play an important role; acquaintance of students with the traditions and customs of Russians; understanding the difficulties of intercultural communication (Russian and Uzbek languages are genetically and typologically completely different); questioning and conducting various tests with the subsequent analysis of their results; comparison of speech-behavioral strategies in Russian and Uzbek cultures; observing others in the learning process; independent communication in the target language in the learning process, which is based on enhancing the cognitive activity of students, accepting and fulfilling various social roles.

\section{REFERENCES}

1. Galskova N.D. Theory of teaching foreign languages: linguodidactics and methods /
N.D. Galskova, N.I. Gez - M :: Publishing Center "Academy", 2004.-336 p.

2. Klyuev E.V. Speech communication: textbook, manual for universities and institutes / E.V. Klyuev. - M .: RIPOL KLASSIK, 2002 - $320 \mathrm{p}$.

3. Koryakovtseva N.F. Modern methods of organizing independent work of foreign language learners: a guide for teachers / N.F. Koryakovtseva. - M .: ARKTI, 2002 - 176 p.

4. Krasnykh V.V. "Own" among "strangers": myth or reality? / V.V. Red. - M .: ITDGK "Gnosis", 2003. - 375 p.

5. Krysin L. P. Sociolinguistic aspects of studying the modern Russian language / L. P. Krysin. - M .: Nauka, 1989 .- P. 188.

6. Safonova V.V. Studying the languages of international communication in the context of the dialogue of cultures and civilizations. - Voronezh: Istoki, 1996.-237 p.

7. Filippova N.V. Methods of teaching nationally-marked vocabulary based on an intercultural approach in a language university (based on the material of German fiction): dis ... cand. ped. Sciences: 13.00.02 / N.V. Filippov; Buryat state un-t. - Ulan-Ude, 2002 - 227 p.

8. Kharchenko E.V. Variants of speech behavior of professional communicators / E.V. Kharchenko // Questions of Philosophy. - 2003. - No. 1. - S. 9-14

9. Tsvetkova T.K. Teaching a foreign language in the context of the sociocultural paradigm / T.K. Tsvetkova // Questions of Philosophy. - 2002. -№2. - S. 109-115.

10. Shatilov S.F. Methodology of teaching German in secondary school: textbook, manual for foreign students. lang. / S.F. Shatilov. - L .: Education, 1977 .- 295 p.

\section{Electronic resources}

11. https://www.advantour.com/rus/uzbekista n/traditions/hospitality.htm. 